\title{
Profile of Calculus Problem Solving of Mathematics Education Students
}

\author{
Muh. Rizal \\ Universitas Tadulako \\ Palu Sulawesi Tengah, Indonesia \\ rizaltberu97@yahoo.com \\ Rita Lefrida \\ Universitas Tadulako \\ Palu Sulawesi Tengah, Indonesia
}

\author{
Linawati \\ Universitas Tadulako \\ Palu Sulawesi Tengah, Indonesia
}

\begin{abstract}
This study is a qualitative research that aims to obtain a profile description student problem solving calculus Mathematics Education FKIP UNTAD. This description is very important for the calculus lecturer in the new school academic, so we can know about the prior knowledge possessed by students of the school, the aspects that have not been, and was known by the students on this course. Thus, teachers can prepare lectures in accordance with the characteristics of these students, so that learning is more meaningful to them. During this time in teaching this course is only based on the curriculum without giving attention to problem solving profile that has been owned by the students, so that the material presented by the teacher is very hard to be accepted by students, because it does not correspond with the experience had ever received before. To achieve these objectives the researchers took the subject of students of mathematics education. To obtain the profile data, the students were given a calculus problem, then explored through the work, think aloud and in-depth interview. The results of the analysis of problem solving calculus student profile obtained by that time to understand the problem, students can not directly assimilate the information received because it is not in accordance with the scheme owned. In this case there are unique aspects or new problems that are not addressed by the subject based on his experiences as different from the experience before. In planning problem based on a similar experience before, in this case derivatives and the definition of absolute values used. Subject to implement appropriate planning that has been made, but did not pay attention to the terms of a problem to be solved. Prior to the final settlement, the subject check the truth of the work that has been done. The student examines the truth of the work by reworking it. If the results obtained in accordance with the work, then concluded the work that has been done is correct.
\end{abstract}

Keywords: Problem solving, calculus,Profile, Polya Step

\section{INTRODUCTION}

Calculus is one of the basic science courses which must be programmed by student's study program Mathematics Education, Chemistry, Biology and Physics in the first two semesters. (Calculus 1 and 2) in the first year together. The purpose of this course is to provide students a basic knowledge of mathematics. Therefore, it is expected for course lecturers to be able to teach this material well, so the course is meaningful for students and can be well understood. If the learning is done meaningful for the students, then the advanced study for this course can be understood well. During this time, the course of this study is still based on the curriculum instead the early knowledge that has been owned by the student. The result for this course in the last few years is not as expected. In the 2012/2013 academic year, out of 159 participants calculus course there are 133 people or $83.65 \%$ at sufficient criteria, less and not pass (score $<71$ ) and only 26 people or $16.35 \%$ are in good and very good criteria (score $\geq 71$ ). While in the 2013/2014 academic year, out of 232 participants there are 157 people or $67.67 \%$ are in sufficient criteria, less and not pass (score $\leq 71$ ) and only 75 people or $32.32 \%$ are in good and very good criteria (value $\geq 71$ ), 1]. The Results from interviews with the calculus 1 lecturer is, for the academic year 2014/2015 , out of 53 participants calculus course there are 28 people or $52.83 \%$ were scored with the criteria fairly and did not pass. Although if the student problem solving profile known by the lecturer, the lecturer know the description of prior knowledge possessed by students, aspects that have not and are known by students, so that lecturers can teach the material based on this aspect. Thus the material that was presented by the lecturers would be more meaningful for students.

Ref. [2] said solving the problem is a thought directly to find a solution / solution to a specific problem. While Polya [3] defines as a problem-solving effort to find a way out of a difficulty to achieve a goal which is not immediately achievable

Based on the above, it can be concluded that solving the problem is an activity to find a way out of a problem to resolve, but not immediately able to find a way to resolve the problem. While solving calculus problems is an activity to find a way out of a calculus that wants to be solved, but not immediately able to find a way to resolve the problem.

According to Polya in [3], there are four steps that can be done in solving the problem, starts from understanding the problem (understand the problem), making planning problem solving(devise a plan),carry out the plan (carry out the plan) 
and last rechecking the results of problem solving that has been done(look back). These four steps are briefly described as follows: a) Understanding the Problem (understand the problem, is a very important step in solving the problem. Without understanding the problem well, someone will not be able to resolve its problems. This step begins with the introduction of what is not known or what is to obtain. Furthermore, understanding of what is known and the data, then see if the data provided sufficient conditions to determine what is to be obtained. b) devise the Plan (devise a plan); in this step needs the capability to see the relationship between the data and the condition exist/available and the unknown/ searchable data. If the relationship is not found, it can be searched by other tools. Furthermore, compiled the problemsolving plan, with the following matters: Do students ever encountered that problem before; whether students can use the theorem to solve those problems. For broad problem can be solved by parts of the problem. Moreover, students can devise a plan to make systematic resolve steps. c) carry out the plan (carry out the plan, resolve plan that have been made previously, then arrange carefully at every step. In the implementation of the plan or complete mathematical model that was created in the previous step, students are expected to pay attention to the principles (rules), to get the correct result. Made a wrong model can cause the incorrect answer in the questions. So, need to checks at every step of the settlement should always be performed to ensure the correctness of the model answers. d) Checking Back (look back), in this step be made to determine whether the settlement is in accordance with the question or not. If the results are not in accordance to the question, it is necessary to re-examination of every step that has been done to get the results. according to the given problem, interpret the results with the problem, and see the possibilities that can be done to resolve the problem. From the results of the investigation can be know where the steps are not appropriate. Thus, inappropriate steps can be rectified.

According to [4], there are five steps to solve the problem, namely: 1) Reading and thinking (read and think), the activities carried out at this stage is to analyze the problem; test and evaluate facts; determine the question, the physical background are visualized, described and understood; the problems translated into the student language and the connection between the parts of problem. 2) Exploring and planning (explore and plan), the activities carried out at this stage is to analyze the data and determine the sufficient condition information, eliminate the things that are unnecessary, organizing data in a table, image or model. 3) Choosing a strategy (select a strategy), strategy is an important part of the problem-solving process to give directions or instructions to students in finding an answer. There are some general strategies and can be selected in solving the problem, namely: (a) recognize the patterns, (b) working backward / reverse, (c) guess and test, (d) conducting experiments or simulations, (e) reducing or expand, (f) organize or complete the list, (g) deduce logically, (h) separating and overcome. 4) Find the answer (find an answer), in this step, all the math skills are used precisely to find an answer. Estimate appropriately, use technology such as calculators help when needed. 5) Review and discuss (reflect and extend), the activities carried out in this step is (a) check the answer: whether the calculation is correct
?, Does the question answered ? whether a rational answer? How do the answers when compared with the estimated result ?, (b) to find alternative solutions, (c) discuss generalizations or into another mathematical concept, (d) to discuss solutions, (e) create interesting variations on the original problem, Thus the problem solving steps issues by Dewey in [5] as follows: 1) Introduction (recognition): to feel a difficulty. (a) recognize the unknown and (b) frustration at the lack of clarity situation. 2) defining (definition): clarify the characteristics of the situation, (a) specialize what is known and unknown, (b) determine the objectives and (c) identifying the standard conditions and extreme. 3) formulation (formulation): states clearly hypotheses and conditions, observe the patterns, (b) identify the steps in planning and (c) selecting or find an algorithm. 4) try out (test): carry out the plan, (a) use existing algorithms, (b) collect additional data, (c) conduct needs analysis, (d) to formulate the problem, (e) tried out for situations that are similar and (f) obtain the results (answers). 5) Evaluation (evaluation): Does the problem definition fits the situation?. (a) Does the hypothesis appropriate? (b) Is the data used correct?, (c) Does the analysis used exact?, (4) Does the analysis used is accordance with the type of data that exist?, (e) Does the results make sense (rational) ?, (f) Does the results can be applied in spot. (question) other? and (g) Does the plan (algorithm) can be applied on the spot (question) other?. Therefore, the problem-solving steps mentioned above shows that the activity in the second and third step of Krulik \& Rudnick same as the second step problem solving Polya. While the first and second activity steps of Dewey same as the first step of problem solving Polya. Based on these, then in this research used Polya solving strategies.

\section{METHODS}

Subjects were students of Mathematics Education for $2016 / 2017$ that program calculus. Subject profile in problem solving will be searched based on problem solving steps by Polya. Polya [3], when understanding the problem, making problem solving plan, carry out the plan and re-examine the work that has been done.

The instrument used, besides researchers themselves as the main instrument also use supporting instruments such tests math skills and calculus problems given symbol M1 and M2. The problems serve in the Table I.

To get a profile of the problem solver's when understanding the problem and make planners taken with depth interview. When carry out the plan of problem solving and rechecking the work that has been done is taken through observation, written tests, thinking-aloud and in-depth interviews.

Once the data is collected, the credibility test conducted using the triangulation of time, comparing the data obtained in different times. If the data obtained with different times have been consistent, then the data is said to be credible.

The data that has been consistently will be analyzed according by [6], namely: (1) review all data, (2) data reduction, (3) data grouping, (4) categorization, (5) coding, and (6) inspection data. 
TABle I. The Equivalent Of Calculus Problems

\begin{tabular}{|c|c|}
\hline $\begin{array}{c}\text { Symbol } \\
\text { Problem }\end{array}$ & \multicolumn{1}{c|}{ Problem Statement } \\
\hline M1 & $\begin{array}{c}\text { Note function, } \\
f x=\frac{1}{x}, x \neq 0 \\
\text { a. Find, } \operatorname{Lim}_{x \rightarrow 0} f(x) \text { and } \operatorname{Lim}_{x \rightarrow 0}|f(x)|, \\
\text { b. Wat can you conclude from these two limits in part a. }\end{array}$ \\
\hline M2 & $\begin{array}{l}\text { Note function, } \\
f x=\frac{1}{2 x}, x \neq 0\end{array}$ \\
& $\begin{array}{l}\text { a. Find }, \operatorname{Lim}_{x \rightarrow 0} \mathrm{f}(\mathrm{x}) \text { and } \operatorname{Lim}_{x \rightarrow 0}|\mathrm{f}(\mathrm{x})|, \\
\text { b. What can you conclude from these two limits in part a. }\end{array}$ \\
\hline
\end{tabular}

\section{RESULTS AND DISCUSSION}

Based on the triangulation of time that there is consistency solution obtained M1 and M2 are performed by students of mathematics education studies at different times, so it was concluded that the students' data is credible. Therefore, only M1 were analyzed for the profile data of problem solving.

The results of the data analysis profile for student's problem solving of calculus is described in accordance with steps Polya as follows:

\section{A. Results of Data Analysis Profile when Understanding MI}

Based on a transcript of an interview with students in understanding M1 was described in the Table II.

To understand M1, students re-reading for information contained in M1. In this aspect the student cannot directly assimilate the information received, because it is not in accordance with the scheme owned. In this case there is a unique aspect or the new M1 $\operatorname{Lim}_{x \rightarrow 0}|\mathrm{f}(\mathrm{x})|$ which cannot be responded to by his experiences as different from the experience (question) ever seen before. But through repeated readings of M1 information can be integrated into the cognitive structure of students to think of the absolute value $|f(x)|$ contained in M1, then connect their knowledge of the definition of absolute value that has been studied before, namely $|\mathrm{x}|=\left\{\begin{array}{c}x ; x \geq 0 \\ -x ; x<0\end{array}\right.$. The definition of the absolute value is used to resolve $\operatorname{Lim}_{x \rightarrow 0}|\mathrm{f}(\mathrm{x})|$ if known, $\mathrm{f}(\mathrm{x})=\frac{1}{x}$ with $\mathrm{x} \neq 0$.

Student's understanding of M1 can also be seen at the implementation plan problem solving M1 as outlined in the article in the following section.
TABLE II. UNDERSTANDING THE PROBLEM

\begin{tabular}{|c|c|}
\hline \multicolumn{2}{|r|}{ Interview about understanding M1 } \\
\hline $\mathrm{P}$ & Before you anwer the question, please read it carefully? \\
\hline $\mathrm{S}$ & Reading the M1 and then paused for a moment \\
\hline $\mathrm{P}$ & What Do You Think? \\
\hline S & Still confused and do not have a clue $\operatorname{Lim}_{x \rightarrow 0}|\mathrm{f}(\mathrm{x})|$ \\
\hline Q & What are you confused? \\
\hline $\mathrm{S}$ & Then read it again, then told me I already understand \\
\hline Q & What do you understand \\
\hline $\mathrm{S}$ & $\begin{array}{l}\text { About an absolute value, I've got a shadow for this absolute } \\
\text { value, and then nod-nod }\end{array}$ \\
\hline $\mathrm{P}$ & Why do you, nodded. What do you think. \\
\hline $\mathrm{S}$ & $\begin{array}{l}\text { seems to find the idea, using the formula of the absolute value } \mid \\
\mathrm{x} \mid=\left\{\begin{array}{c}x ; x \geq 0 \\
-x ; x<0\end{array} \text {, Then silence }\right.\end{array}$ \\
\hline Q & What do you think? \\
\hline $\mathrm{S}$ & $\begin{array}{l}\text { Still confused in } \operatorname{Lim}_{x \rightarrow 0} f(x) \text {, then read it again, and then said } \\
\text { already understood about the question }\end{array}$ \\
\hline $\mathrm{P}$ & What do you understand from the question? \\
\hline $\mathrm{S}$ & $\begin{array}{l}\text { There are two forms to search, find the value of } \operatorname{Lim}_{x \rightarrow 0} f(x) \\
\text { where } f(x)=1 / x \text { with } x \neq 0 \text { and find the value of } \operatorname{Lim}_{x \rightarrow 0}|f(x)| \\
\text { where } f(x)=1 / x\end{array}$ \\
\hline $\mathrm{P}$ & There is other information that you get from these problems \\
\hline $\mathrm{S}$ & There is no more \\
\hline
\end{tabular}

\section{B. Results of Data Analysis Profile when Planning Problem Solving $M 1$}

Based on the transcript of the interview and thinking aloud can be described in a plan profile M1 solving by students was described in the Table III.

Based on an understanding and experiences M1 that have been obtained before, then $\operatorname{Lim}_{x \rightarrow 0}|\mathrm{f}(\mathrm{x})| \mid$ if known, $\mathrm{f}(\mathrm{x})=\frac{1}{x}$ with $\mathrm{x} \neq 0$ using the formula plan of the absolute value $|\mathrm{x}|=$ $\left\{\begin{array}{c}x ; x \geq 0 \\ -x ; x<0\end{array}\right.$ and $\operatorname{Lim}_{x \rightarrow 0} \mathrm{f}(\mathrm{x})$ if known, $\mathrm{f}(\mathrm{x})=\frac{1}{x}$ with $\mathrm{x} \neq 0$ solved by using a derivative work because the value of $\mathrm{x}=0$ if put directly into the $\mathrm{f}(\mathrm{x})=\frac{1}{x}$ the value is infinity, in accordance with a similar experience ever seen before. This is in line with that proposed by Ausubel [7] that the information can be assimilated significantly, if a person can connect with prior knowledge. The unique aspect of this experience led to changes in cognitive structure. Piaget [8] states that assimilation is the incorporation of new events into intelligence as a scheme or concept. 
TABLE III. Plan ThE PROBLEM SOlVING

\begin{tabular}{|l|l|}
\hline \multicolumn{2}{|c|}{ Interview about solving planning M1 } \\
\hline $\mathrm{P}$ & $\begin{array}{l}\text { Because you have already understand, how do you solve } \\
\operatorname{Lim}_{x \rightarrow 0} \mathrm{f}(\mathrm{x}) \text { and } \text { Lim }_{x \rightarrow 0}|\mathrm{f}(\mathrm{x})| \text { if known, } \mathrm{f}(\mathrm{x})=1 / \mathrm{x} \text { with } \mathrm{x} \neq \\
0 .\end{array}$ \\
\hline $\mathrm{S}$ & $\begin{array}{l}\operatorname{Lim}_{x \rightarrow 0}|\mathrm{f}(\mathrm{x})| \mathrm{I} \text { think using absolute price rule. } \\
\text { Because }|\mathrm{x}|=\left\{\begin{array}{l}x ; x \geq 0 \\
-x ; x<0\end{array}\right.\end{array}$ \\
\hline $\mathrm{P}$ & So, how about $\operatorname{Lim}_{x \rightarrow 0} \mathrm{f}(\mathrm{x}) ?$ \\
\hline $\mathrm{S}$ & Solve directly in line with my thinking and understanding \\
\hline $\mathrm{P}$ & What does that mean? \\
\hline $\mathrm{S}$ & In accordance that had been taught before \\
\hline
\end{tabular}

\section{Results of Profile Data Analysis When Implementing The} Planning Solution M1

Written results that have been made by students Mathematics Education in implementing the planning solution M1 as follows:

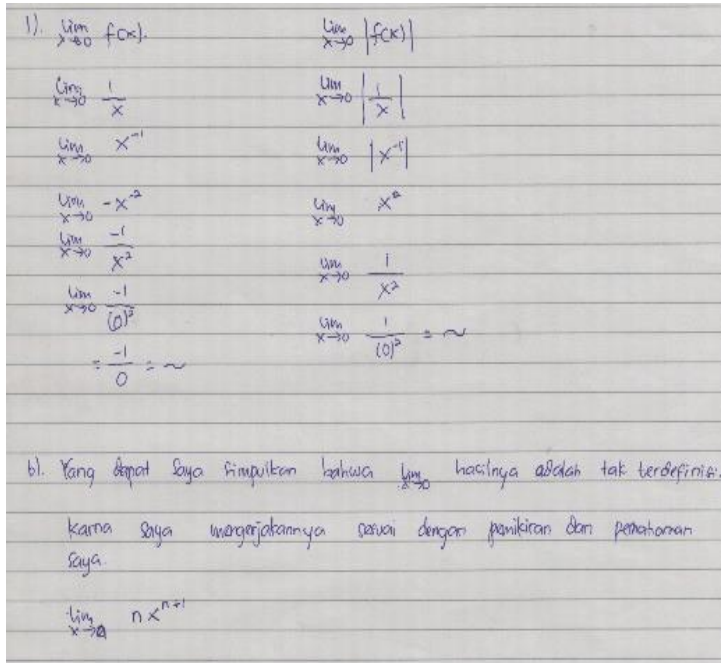

Fig. 1. Answer Sheet of Student

Students solve M1 according to plan. The plan directly assimilated into the cognitive structure and implemented as a similar experience ever seen before by finding $\operatorname{Lim}_{x \rightarrow 0} f(x)$ by finding the first derivative from $f(x)=\frac{1}{x}$ without noticing that the problem $f(x)=\frac{1}{x}$ with $\mathrm{x} \neq 0$ undefined at $\mathrm{x}=0$, so that $\operatorname{Lim}_{x \rightarrow 0} \mathrm{f}(\mathrm{x})$ need to be reviewed unilateral limit.

For $\operatorname{Lim}_{x \rightarrow 0}|\mathrm{f}(\mathrm{x})|$, the students express and write smoothly as planned using the definition of the absolute value $|\mathrm{x}|=$ $\left\{\begin{array}{c}x ; x \geq 0 \\ -x ; x<0\end{array}\right.$. When solve this, to eliminate the absolute values from $\operatorname{Lim}_{x \rightarrow 0}\left|\frac{1}{x}\right|$ done by squaring, so the results are an infinite. Interview implementation was described in the Table IV.
TABLE IV. CARRY OUT THE PlaN

\begin{tabular}{|l|l|}
\hline \multicolumn{2}{|c|}{ Interviews implementation of solving M1 } \\
\hline P & $\begin{array}{l}\text { What conclusion the results you get from } \operatorname{Lim}_{x \rightarrow 0} \mathrm{f}(\mathrm{x}) \text { dan } \\
\text { Lim }_{x \rightarrow 0}|\mathrm{f}(\mathrm{x})| \text { ? }\end{array}$ \\
\hline $\mathrm{S}$ & The result is an infinite \\
\hline $\mathrm{P}$ & Where did you learn this solving \\
\hline $\mathrm{S}$ & In accordance with my thinking and understanding \\
\hline $\mathrm{P}$ & What do you mean? \\
\hline $\mathrm{S}$ & In accordance that had been taught before \\
\hline
\end{tabular}

Conclusion of $\operatorname{Lim}_{x \rightarrow 0} \mathrm{f}(\mathrm{x})$ and $\operatorname{Lim}_{x \rightarrow 0}|\mathrm{f}(\mathrm{x})|$ is undefined (not have), which is based on the thinking and understanding. The Students do not pay attention to the terms of solving the problem $\operatorname{Lim}_{x \rightarrow 0} \mathrm{f}(\mathrm{x})$ when $(x)=\frac{1}{x}$, $\mathrm{x} \neq 0$.

Before reach the final solving, students of mathematics education re-reading and re-calculate mentally from any steps that have been made.

\section{Results of Data Analysis Profile When Re-Examine The Work for $M 1$.}

The results of student interviews in re-examine the work carried out was described in the Table V.

TABLE V. LOOKING BACK.

\begin{tabular}{|c|c|}
\hline \multicolumn{2}{|r|}{ Interview about re-examine the work for M1 } \\
\hline $\mathrm{P}$ & How do you believe that the answers you're doing is right? \\
\hline S1 & $\begin{array}{l}\text { because the value of } \operatorname{Lim}_{x \rightarrow 0} \mathrm{f}(\mathrm{x}) \text { obtained that the results is an } \\
\text { infinite while the value of } \operatorname{Lim}_{x \rightarrow 0}[\mathrm{f}(\mathrm{x})]=\text { infinite, because the } \\
\text { absolute value of the negative eliminated. }\end{array}$ \\
\hline $\mathrm{P}$ & Continue \\
\hline S1 & Rework using derivative \\
\hline $\mathrm{P}$ & How? \\
\hline S1 & The results were similar with before \\
\hline $\mathrm{P}$ & Are you sure that the answer you are doing is correct? \\
\hline S & Yes Sir \\
\hline
\end{tabular}

Based on the description of the results of the interview transcripts, can be described in a profile for student's problem solving in re-examine the results of the work that has been done for M1 as follows.

In order to check the validity of the work that has been made, these students recalculate, and then compare the results of the work that has been done. Therefore, the calculation results together with the results of his work, then summed up the results of work that has been obtained is correct. 


\section{IV.CONCLUSIONS AND RECOMMENDATIOS}

\section{A. Conclusions.}

Based on the analysis concluded that the profile of problem-solving calculus student of Mathematics Education as follows:

- Students understand the problem can not directly assimilate the information received, because not accordance with schema owned. In this case there are unique or new aspects that can not respond because it is different from the experience before.

- Students make the plan for the problem solving based on similar experiences that have been obtained before and ignore the terms of the problem solving.

- Students implement problem-solving plan as planned and based on similar experiences before. The student does not check the terms of a problem that can be solved, so that the results are incorrect. In addition, before reach the final solving, the student has to check every step taken.

- Students check the veracity of the results by reworking it. If the results obtained is accordance with the work, it was concluded the work that has been done is correct.

\section{B. Recommendations:}

Need for further research on the learning model problemsolving calculus based on the profile of students, untill the basic science subjects studied in the first year together can be understood meaningfully.

\section{ACKNOWLEDGMENT}

Thank You to Tadulako University, Palu Indonesia which has funded through FKIP DIPA funds.

\section{REFERENCE}

[1] Rizal, Hamid \& Linawati. 2014. Penerapan Model Pembelajaran Kooperatif Round Robin untuk meningkatkan Kemampuan Mahasiswa Program Studi Pendidikan Matematika FKIP Untad dalam Menyelesaikan Masalah Turunan Fungsi. Hasil Penelitian, tidak dipublikasi, Palu: FKIP Untad

[2] Solso, R. L., Maclin, O. H. \& Maclin, M. K. 2008. Psikologi Kognitif, Edisi kedelapan. Jakarta: Penerbit Erlangga

[3] Rizal, M. 2011. Proses Berfikir Siswa SD Berkemampuan Matematika Tinggi dalam Melakukan Estimasi Masalah Berhitung. Prosiding Seminar Nasional Penelitian, Pendidikan, dan Penerapan MIPA Tanggal 14 Mei 2011, hal 19-28 Yogyakarta: FMIPA, Universitas Negeri Yogyakarta

[4] Krulik, S. \& Rudnick, J. A. 1995. The New Sourcebook for Teaching Reasoning and Problem Solving in Elementary School. Needham Heights: Allyn \& Bacon

[5] Swadener, M. 1985. Teaching Problem Solving In Mathematics, Colorado: University of Colorado

[6] Moleong, L. J. 1988. Metodologi Penelitian Kualitatif. Bandung:Remaja Rosdakarya Bandung

[7] Novak, D., 2011. A Theory of Education: Meaning Learning Underline The Constructive Integration of Thinking, Feeling, and Acting Leading to Empowerment For Commitment and Responsibility. Aprenzagen Significativa em Revista/Meaningful Learning Review. Vol 6(2), pp. 14.

[8] Brooks, J. G \& Brooks, M. G. 1993. In Search of Understanding: The Case for Constructivist Classroom. Alexandria, VA: The Association for Supervision and Curriculum Development. 